\title{
BODY GROWTH OF GOAT KIDS IN ORGANIC FARMING
}

\author{
Zvonko Antunović, Josip Novoselec, Željka Klir \\ Faculty of Agriculture in Osijek, University of J.J. Strossmayer, Department of Animal Science, \\ P. Svačića 1d, 31000 Osijek, Croatia, \\ zantunovic@pfos.hr
}

\begin{abstract}
The aim of this research was to determine the growth and development of goat kids from organic farming during the period of suckling and fattening. The research was conducted on organic farm with 15 goat kids French Alpine breed, during the suckling period (from kidding to 75 days) and the beginning of the fattening period (during the first 20th day of fattening). Goat kids were weighed at birth, 15, 45 and 75 days in the period of suckling, when weaning followed, and at the age of 95 days of fattening. Goat kids were fed a mixture of concentrated feed $(50 \%$ barley, $30 \%$ corn, $10 \%$ wheat and 10\% sunflower meal) and alfalfa hay ad libitum, while during the period of suckling. Goat kids were suckling ad libitum. Rearing and feeding of goat kids were in accordance with the Regulations on organic livestock production. Immediately after weighing goat kids were taken body measures (height of withers, trunk length, circumference and width of chest, circumference and leg length and cannon bone circumference), body condition scores and were calculated indices of anamorphosis and body proportions as well as daily gain. The determined body weight (from $4.39 \mathrm{~kg}$ to $15.72 \mathrm{~kg}$ ) respectively, $18.82 \mathrm{~kg}$ ) and daily gain $(151 \mathrm{~g}$ or $155 \mathrm{~g}$ ) of goat kids in suckling period and the beginning of the fattening period and indicate the satisfied result of feeding and rearing in the organic conditions. With increasing the age of goat kids body weight was growing, as well as daily gain and body condition scores (from 2.53 to 2.89), anamorphosis indices (from 45.00 to 61.87) and body proportions (from 16.71 to 32.96). Determined indicators of growth and development of goat kids show satisfactory rearing conditions in organic farming.
\end{abstract}

Key words: goat kids; body growth; organic farming

\section{ПРИРАСТ НА ЈАРИЊА ВО ОРГАНСКО ПРОИЗВОДСТВО}

Целта на ова испитување беше да се одреди прирастот и развојот на јарињата во органско земјоделско производство, во периодот на доење и гоење. Испитувањето беше спроведено на органска фарма кај 15 јариња од расата француска алпина за време на периодот на доење (од јарење до 75 дена) и на почетокот на периодот на гоење (во текот на првите 20 дена на гоење). Јарињата беа мерени при раѓае, на 15 , на 45 и на 75 дена во периодот на доење, по кој следуваше одбивање, и на возраст од 95 дена во периодот на гоење. Тие беа хранети со концентратна смеска (50\% јачмен, $30 \%$ пченка, $10 \%$ пченица и $10 \%$ сончогледово ќуспе) и со луцеркино сено „по желба“ во текот на дојниот период. Јарињата цицаа исто така „по желба“. Одгледувањето и исхраната на јарињата беа во согласност со прописите за органско сточарско производство. Веднаш по мерењето на телесната маса, од јарињата беа земени повеќе мерки од телото: висина на грбот, должина на трупот, обем и ширина на градите, обем и должина на нозете и обем на лисната коска, извршена оцена на телесната кондиција, а беа пресметани и индексите на анаморфозност и телесните пропорции, како и дневниот прираст. Утврдените вредности на телесната маса (од 4,39 $\mathrm{kg}$ до 15,72 $\mathrm{kg}$ односно, 18,82 kg) и дневниот прираст $(151 \mathrm{~g}$ или 155 г) на јарињата во текот на дојниот период и во почетокот на периодот на гоење, покажуваат задоволителни резултати од исхрана и одгледување во органски услови. Со зголемување на возраста на јарињата, во пораст се телесната маса, дневниот прираст и оцената на телесната кондиција $(2,53$ до 2,89$)$, индексот на анаморфозност $(45,00$ до 61,87) и пропорциите на телото (од 16,71 до 32,96 ). Утврдените индикатори на растот и развојот на јарињата покажуваат дека условите за одгледување при органско земјоделско производство се задоволителни.

Клучни зборови: јариња; телесен прираст; органско земјоделско производство

\section{INTRODUCTION}

Although interest for organic livestock production is increasing, organic farming of domestic animals is less frequent (Lu et al., 2010). Goats are with plenty of quality products (milk, meat, skin, hair) capable, with minimal inputs in production, reside in his environment without pollution, while 
the production, contribute to the sustainable management of land and land clearing (Antunović et al., 2011). There are little relevant scientific and professional publications that deal with environmental issues of goat kids in organic farming ( $\mathrm{Zu}-$ rita et al., 2009; Antunović et al., 2007 and 2013). Most of the research are aimed toward testing the productivity of goats in organic farming (Antunović et al., 2006 and 2007; Kompan and Kastelic, 2008; Rahman, 2009; Miotello et al., 2009; Tudisco et al., 2010). Suckling young goat kids are very sensitive category of animals that may be affected by various disorders and undeveloped growth because in the early life they are nonresistant due to the underdevelopment of certain organs and biological mechanisms, and thus their nonfunctional in the real sense (Antunović et al., 2008). The goat kids are especially sensitive on the changes in nutrition and rearing. When feeding goat kids with low quality diets, retarded growth and development may occur, which is later very difficult to compensate with correction of feeding (Pavić et al., 2005).

The aim of this study was to determine growth and development of goat kids in organic farming during suckling and fattening period.

\section{MATERIALS AND METHODS}

The study was conducted on certified organic family farm located in Eastern Slavonia (northwest, approximately $30 \mathrm{~km}$ from Osijek) with 15 goat kids of French Alpine breed during the suckling period (from kidding to 75 th day) and the beginning of the fattening period (during the first 20 days of fattening). Goat kids are selected from litters where they were single, and goats were in $4^{\text {th }}$ lactation. Goat kids were weighed and measured at birth, $15^{\text {th }}, 45^{\text {th }}$ and $75^{\text {th }}$ day in the suckling period, when weaning occurred, and at the age of $95^{\text {th }}$ day of fattening. In the suckling period goat kids were suckling mothers and fed with mixture of concentrated feed $(50 \%$ barley, $30 \%$ corn, $10 \%$ wheat and $10 \%$ sunflower meal) as well as alfalfa hay ad libitum. After weaning goat kids were fed only with the same concentrate mixture and alfalfa hay ad libitum. Rearing and feeding of goat kids were in accordance with the Regulations of organic livestock production (2002). Immediately after weighing body measurements (height of withers, trunk length, circumference and width of chest, circum- ference and leg length and cannon bone circumference) were taken from kids, and then average daily gain was calculated. Body condition score of kids were assessed according to Santucci and Maestrini (1985) with grades from 1 to 5 , and indices of anamorphosis as well as body proportions were calculated according to Chiofalo et al. (2004).

The research results were analyzed in the computer program Statistica (2008) and expressed as arithmetic mean (mean) and standard deviation (sd).

\section{RESULTS AND DISCUSSION}

In Tables 1 and 2 production characteristics and exterior measures of goat kids in organic farming are present.

By analysis of Tables 1 and 2 it is shown that the goat kids developed and gained faster in the suckling period compared to the beginning of fattening. This was expected because the goat kids in the beginning of fattening were in unfavorable situation, due to changes in diet, although they were adapted to the specified diet during suckling period too. During weaning period of goat kids, reduced feed intake and conversion may occur (Toukourou and Peters, 1999). Therefore, the appropriate protein intake from solid feed is important for successful weaning of goat kids (Greedwood, 1993). The highest daily gain of goat kids was achieved in the suckling period from 1 to 15 days and from 1 to 45 days (175.29 and $175.07 \mathrm{~g}$, respectively). The similar conclusions in conventional conditions in the Alpine breed goats determined Vnučec et al. (2005), but the goat kids' achived gains in the period from $1_{\text {st }}$ to $19_{\text {th }}$ day were significantly higher $(220.76 \mathrm{~g})$. Bartocci et al. (1986) present that the largest increment of goat kids occurs in the first month of life and later is falling.

With increasing of goat kids age, growing weight increased, as well as daily gain and body condition scores (of 2.53 to 2.89), indices of anamorphosis (from 45.00 to 61.87) and indices of body proportions (from 16.71 to 32.96 ), that are shown in Table 3. Identified indicators of growth and development of goat kids show satisfactory rearing conditions in organic farming. Although with good quality feeding, much better production effects in goat kids may be accomplished. 
T a b $\quad$ b e 1

The production characteristics of goat kids in organic farming (mean $\pm s d$ )

\begin{tabular}{lccccc}
\hline \hline Time of measuring (day) & Birth & $15^{\text {th }}$ & $45^{\text {th }}$ & $75^{\text {th }}$ & $95^{\text {th }}$ \\
\hline Body weight, $\mathrm{kg}$ & $4.39 \pm 0.91$ & $7.02 \pm 1.15$ & $12.27 \pm 2.55$ & $15.72 \pm 2.28$ & $18.82 \pm 2.13$ \\
\hline Time of measuring (day) & ${\text { from } 1^{\text {st }} \text { to } 15^{\text {th }}}^{\text {nath }}$ & from $1^{\text {st }}$ to $45^{\text {th }}$ & from $1^{\text {st }}$ to $75^{\text {th }}$ & from $75^{\text {th }}$ to $95^{\text {th }}$ & from $1^{\text {st }}$ to $95^{\text {th }}$ \\
\hline Daily gain, g & $175.29 \pm 72.44$ & $175.07 \pm 53.03$ & $151.08 \pm 24.75$ & $155.07 \pm 66.15$ & $151.92 \pm 15.87$ \\
\hline \hline
\end{tabular}

Table 2

Exterior measures of goat kids in organic farming (mean $\pm s d)$

\begin{tabular}{lcccc}
\hline \hline \multirow{2}{*}{ Body measure, $\mathrm{cm}$} & \multicolumn{4}{c}{ Time of measuring (day) } \\
& $15_{\text {th }}$ & $45_{\text {th }}$ & $75_{\text {th }}$ & $95_{\text {th }}$ \\
\hline Height of withers & $41.97 \pm 3.24$ & $47.07 \pm 5.03$ & $51.80 \pm 2.98$ & $57.03 \pm 2.83$ \\
Trunk length & $40.51 \pm 3.56$ & $48.77 \pm 4.52$ & $53.57 \pm 4.18$ & $58.96 \pm 3.31$ \\
Circumference of chest & $43.33 \pm 2.80$ & $51.80 \pm 4.12$ & $5.50 \pm 3.81$ & $59.37 \pm 3.00$ \\
Width of chest & $7.90 \pm 0.71$ & $9.83 \pm 1.82$ & $9.93 \pm 0.78$ & $10.20 \pm 1.08$ \\
Leg length & $16.37 \pm 0.61$ & $18.63 \pm 0.90$ & $21.53 \pm 2.77$ & $23.27 \pm 3.04$ \\
Circumference of leg & $20.93 \pm 3.29$ & $24.70 \pm 1.93$ & $28.83 \pm 2.62$ & $26.07 \pm 2.02$ \\
Cannon bone circumference & $7.00 \pm 0.53$ & $7.47 \pm 0.64$ & $7.52 \pm 0.61$ & $7.63 \pm 0.55$ \\
\hline \hline
\end{tabular}

sd - standard deviation

Table 3

Indices of physical development of goat kids in organic farming (mean $\pm s d$ )

\begin{tabular}{lcccc}
\hline \hline \multicolumn{1}{c}{ Index } & \multicolumn{4}{c}{ Time of measuring (days) } \\
& $15^{\text {th }}$ & $45^{\text {th }}$ & $75^{\text {th }}$ & $95^{\text {th }}$ \\
\hline Body condition scores & $2.53 \pm 0.58$ & $2.67 \pm 0.37$ & $2.75 \pm 0.45$ & $2.89 \pm 0.27$ \\
Anamorphosis index & $45.00 \pm 5.52$ & $57.24 \pm 5.42$ & $59.71 \pm 7.43$ & $61.87 \pm 4.39$ \\
Body proportion index & $16.71 \pm 2.43$ & $25.91 \pm 3.71$ & $30.28 \pm 3.48$ & $32.96 \pm 2.76$ \\
\hline \hline sd - standard deviation & &
\end{tabular}

Antunović et al. (2006, 2007 and 2013) determined similar birth weight of goat kids in organic farming. In studies of the same authors (Antunović et al., 2012) slightly lower birth weight of goat kids were found, compared with this research. Pavić et al. (1988) in conventional breeding of goat kids determined similar birth weight of kids Alpina $(4.11 \mathrm{~kg})$ and average daily gain $(149.7 \mathrm{~g})$ in the period of kiding to the $102^{\text {nd }}$ day of life. However, Mioč (1988) and Majid et al. (1993) determined lower birth weight of Alpine kids (3.55 kg and 3.8 $\mathrm{kg}$ ). In the study by Mioč et al. (2011) that was conducted with goat kids of Croatian Spotted breed, lower birth weight $(2.28 \mathrm{~kg})$, lower weight at weaning (186 days $23 \mathrm{~kg}$ ) and average daily gain (115.43 g) of goat kids were determined. In the study by Marquez et al. (2007), lower birth weight and weaning weight at the age of 60 days in the goat kids of Alpine breed (2.11 and $13.20 \mathrm{~kg}$ ) were recorded, as well as slightly higher daily gain of kids until weaning (186 g). The above is in accordance with the conclusions by Leas-Fattback and Peters (1995) that highlight a significant variations birth weight of goat kids that depend on the influence of breed, nutrition and season. In the goat kids from organic farming at the age of $70_{\text {th }}$ to $110_{\text {th }}$ day in the research by Antunovic et al. (2008) similar weight and average daily gain (15.93 and 
$21,54 \mathrm{~kg}$ and $140.27 \mathrm{~g}$ ) were determined, as well as determined body measures and indices of physical development.

\section{CONCLUSION}

Based on conducted research we can conclude that the body growth of goat kids in organic farming was satisfactory, although the results may be improved by high quality feeding and thus provide efficient production.

\section{REFERENCES}

[1] Antunović, Z., Senčić, Đ., Vincek, L., Kanisek, J., Steiner, Z., Šperanda, M.: Breeding performance and economic efficiency of organic goat breeding. Proceedings of $41_{s t}$ Croatian \& 1 st International Symposium on Agriculture, Opatija, February 13-17, 2006, pp. 113-114, 2006. (in Croatian)

[2] Antunović, Z., Senčić, Đ., Šperanda, M. Domaćinović, M., Steiner, Z.: Productive traits of goats and kids in organic farm production. Proceedings of 42 nd Croatian \& 2nd International Symposium on Agriculture, Opatija, February $13-16,2007$, pp. 518-521, 2007. (in Croatian)

[3] Antunović, Z., Šperanda, M., Senčić, Đ., Domaćinović, M., Novoselec, J.: Efficiency of probiotic preparation „probios $2 b^{\text {“ }}$ in goat kids feeding. Krmiva, 50, 2, 73-78 (2008). (in Croatian)

[4] Antunović, Z.: Organic farming of sheep and goats. In: Organic zootechique. Editor Senčić, Đ., Poljoprivredni fakultet u Osijeku, pp. 92, 2011. (in Croatian)

[5] Antunović, Z., Novoselec, J., Klir, Ž.: Does the drought affects on the reproductive characteristics of goats in organic breeding? Proceedings of $11^{\text {th }}$ Alps-Adria scientific workshop, Smolenice, Slovakia, 26-31. 3. 2012, pp. 419422, 2012.

[6] Antunović, Z., Varžić, G., Novoselec, J., Šperanda, M., Klir, Ž.: Influence of production system on body growth and development of goat kids. Proceedings of 48 th Croatian \& 8th International Symposium on Agriculture, Dubrovnik, February 17-22, 2013, pp. 707-711, 2013. (in Croatian).

[7] Bartocci, S., Terzano, G. M., Borghese, A.: Intensive kid production. 2., Live and slaughter data in Saanen aged 35 and 48 days. Annali dell'Instituto Sperimentale per la Zootechnia, 19, 2, 109-121 (1986).

[8] Chiofalo, V., Liotta, L., Chiofalo, B.: Effects of the administration of Lactobacilli on body growth and on the metabolic profile in growing Maltese goats kids. Reprod. Nutr. Dev., 44, 449-457 (2004).

[9] Greenwood, P. L.: Rearing systems for dairy gotas. Small Ruminant Research, 10, 189-199 (1993).

[10] Kompan, D., Kastelic, M.: Productivity of Slovenian alpine goat in the conventional and organic farming system, www.icar.org/niagara, 2008.

[11] Leas-Fattback, C., Peters, P.C.: A comparative study of performance of Egyptian goats breeds. II. Growth per- formance and productivity. Archiv für Tierzucht, 38, 563575 (1995).

[12] Lu, C. D., Gengyi, X., Kawas, J. R.: Organic goat production, processing and marketing. Opportunities, challenges and outlook. Small Ruminant Research, 89, 102-109 (2010).

[13] Majid, A. M., Cartwright, T. C., Yazman, J. A., FitzHugh, H. A. J. R.: Performance of five breeds of dairy goats in southern United States. 1. Reproductive traits and maturing pattern. World Review of Animal Production, 28, 2, 15-23 (1993).

[14] Marquez, A. P., Saucedo, J. S., Montano, M., Guerrero, J. N.: Estimates of genetic parameters for weight in the progeny of Nubian, French alpine, Saanen, Toggenburgh, and Spanish goats mated to Boer sires. Proceedings Western section, American Society of Animal Science, 57, 113-115 (2007).

[15] Mioč, B.: Relationship of breed and growth intensity and chemical composition of kid's meat. Agriculturae conspectus scientificus, 63, 4, 179-186 (1998).

[16] Mioč, B., Sušić, V., Antunović, Z., Prpić, Z., Vnučec, I., Kasap, A.: Study on birth weight and pre-weaning growth of Croatian multicolored goat kids. Veterinarski arhiv, 81, 3, 339-347 (2011).

[17] Miotello, S., Bondesan, V., Bailoni, L.: Organic farming of dairy goats in the Veneto region: feeding management and milk quality. Italian Journal of Animal Science, $\mathbf{8}$, suppl. 2, 420-42 (2009).

[18] Pavić, V., Mioč, B., Sušić, V., Prpić, Z.: Kids nutrition after weaning. Stočarstvo, 59, 1, 61-70 (2005).

[19] Pavić, V., Mioč, B., Crnojević, Z., Kitonić, A.: Some reproductive traits of goats in intensive milk production system. Agriculturae conspectus scientificus, 53, 87-94 (1988).

[20] Rahmann, G.: Goat milk production under organic farming standards. Tropical and Subtropical Agroecosystems, 11, 105-108 (2009).

[21] Regulations on organic livestock production, Official Gazette of Republic of Croatia, 13, 02, 2002.

[22] Santucci, P. M., Maestrini, O.: Body condition of dairy goats in extensive systems of production: method of estimation. Ann. Zootech., 34, 471-490 (1985).

[23] Statistica-Stat Soft, Inc. version 8.0 (2008), www.statsoft.com.

[24] Toukourou, Y., Peters, K. J.: Auswirkungen restriktiver Ernährung auf die Wachstumsleistung von Ziegenlämmern. Archiv für Tierzucht, 42, 3, 281-293 (1999).

[25] Tudisco, R., Cutringelli, M. I., Calabro, S., Piccolo, G., Bovera, F., Guglielmelli, A., Moniello, G., Infascelli, F.: Influence of organic systems on milk fatty acids profile and CLA in goats. Small Ruminant Research. 88, 151155 (2010).

[26] Vnučec, I., Mioč, B., Pavić, V., Kapš, M.: Prolificacy of goats and daily gains of kids in intensive breeding system. Zbornik radova. XL. Croatian Symposium on Agriculture, Opatija 15-18. 2. 2005. Croatia, 647-648, 2005. (in Croatian)

[27] Zurita, M. E., Camacho, J., Pleguezuelos, Delgado, J.V.: Organic vs. conventional herd effects on the weights and daily gains in murciano-granadina kids. Tropical and Subtropical Agroecosystems, 11, 98-99 (2009) 